\title{
Terrorism and Civil Aviation Security: Problems and Trends
}

Jangir Arasly*

\section{General Trends in Present-Day Terrorism}

The terrorist attacks of 11 September 2001 marked the start of a new period in modern history. This period is one characterized by instability, unpredictability, and the reshaping of complex systems, including both traditional and new types of challenges and threats. Of particular significance in the last and most dangerous category is, beyond any doubt, the emergence of terrorism as a truly global threat.

It has to be kept in mind that terrorism, as an independent and self-reproducing socio-political phenomenon of violence, can be seen throughout the history of human civilization. However, in the twenty-first century, terrorism has evolved into a major geopolitical factor, capable of causing a systemic crisis at the global level. Some of the distinctive (albeit not unique) characteristics of modern terrorism - also labeled "international terrorism," "new wave terrorism," "mega-terrorism," "fourth-generation terrorism"- are as follows ${ }^{1}$ :

- Qualitative change of content;

- Shift to a strategic approach and a particular type of warfare;

- Perpetual reproduction and build-up;

- Transformation into mass movements;

- Permanent dynamics;

- Fluid, mutable nature - convergence;

- Increasing importance of non-state actors;

- Growing professionalization;

- Escalation of technological sophistication;

- Weapons of mass effect, techno-terrorism;

- Increasing reliance on information technologies and networks;

- Cyber-terrorism, psycho-terrorism.

The above-mentioned elements make it possible to identify the overall scope of a modern global process that some politicians and experts in terrorism are referring to as

* Jangir Arasly is an advisor on International Issues to the Minister of Defense of Azerbaijan, and a member of the PfP Combating Terrorism Working Group.

1 Jangir Arasly, paper presented to a meeting of the Combating Terrorism Working Group of the PfP Consortium, Sarajevo, February 2004. 
"World War Four." Among the basic players in this process-along with nationstates - are non-state actors, including terrorist structures, networks, and movements.

It should be noted that the conflict outlined above is closely connected to another, no less significant and all-encompassing phenomenon - the process of globalization. Its most crucial aspect - even more than the revolution in information technologies - is the spread of the "transportation revolution" around the world, which paves the way for the rapid and free movement of people, commodities, and services on a global scale. Recognizing this, civil aviation is the aspect of this revolution that has wrought the greatest change. Nowadays, air transport is in position to convey people and cargo to the remotest corners of the Earth, from anywhere else, in a journey of slightly over twenty-four hours. It is important to note that aviation is today's most dynamic, fastest developing area of transportation. An eloquent testimony to its importance and pace of development are the following quantitative indices: there are approximately 10,000 air transport companies presently operating in the world, using more than 15,500 passenger airliners (ignoring cargo planes and light aircraft) and landing at over 5,000 airports.

Regretfully, this positive tendency also has a negative side. By virtue of its functional significance and vulnerability, civil aviation is increasingly becoming the focus of the operational activity of different terrorist structures as a subject (rather than an implement) of their actions. This, in turn, makes it critical to take practical steps toward tightening the level of security in the area of civil aviation.

\section{Genesis and Operational Chronology of Terrorism in Transport Aviation}

It should be noted that the appearance of terrorism has practically concurred with the rise of aviation as a mode of transportation. The first registered incident of aviation terrorism goes back to 1930, when Peruvian insurgents seized an airplane to scatter propaganda leaflets. ${ }^{3}$ But this practice did not become customary in the subsequent four decades, primarily owing to the effect of global factors (World War Two, etc.).

The starting date of modern aviation terrorism, as we see it now, is 22 July 1968, when three gunmen from the Popular Front for the Liberation of Palestine (PFLP) hijacked a passenger airliner of the Israeli airline $\mathrm{El} \mathrm{Al}$ on a flight from Rome to TelAviv, and demanded to exchange hostages for their comrades-in-arms who were imprisoned in Israel. ${ }^{4}$ This operation, although it was the twelfth case of civilian aircraft seizure in 1968, was qualitatively different in its content and ultimate aim. It was the first time that an aircraft had ever been hijacked not out of criminal motivation or for personal reasons, but with the specific goal of politically pressuring an opponent and using the incident as a propaganda message to bring a political cause to the world's notice. It was a deliberate creation of a crisis situation and an immediate threat to the

2 J. Aras, World War Four. The Handbook on Non-government Paramilitary Systems (Baku: Sada publishing house, 2002), 6 .

3 O. Gubarev, Secrets of Air Terrorism (Moscow: Veche, 2002), 11.

4 Bruce Hoffman, Terrorism. The Insight (Moscow: 2003), 77. 
lives of hostages that contributed to shaping a favorable political and psychological context for coercing an opponent into direct talks (which is a de facto form of recognition) and complying with demands. It is no mere coincidence that late 1960s and the early 1970s were marked by explosive growth in the number of terrorist acts directed at air transport, most of which followed a typical pattern: armed seizure of an airliner; hijacking to a safe airport; and issuing demands of a political nature under the threat of execution of hostages.

Later, in the 1980s, the dangerous tendency toward the further spread of aviation terrorism as a tool of political pressure and propaganda came to an end. Contributing to this were various factors, including:

- Deployment and rapid improvement of the technical means of airport security, which made it difficult for terrorists to covertly carry arms and ammunition on board airliners;

- Creation and effective use of special anti-terrorist teams (as deployed in the rescue of hostages in Mogadishu, Entebbe, etc.);

- Implementation of countermeasures by some states against leaders of terrorist structures as retribution and reprisals for already committed acts of aviation terrorism;

- Changes in public awareness, namely the perception of hijacking as an explicitly terrorist act, rather than as an "act of struggle for freedom."

Although the trend toward aviation terrorism had stalled, the tendency toward the politically motivated hijacking of airliners did not disappear. Starting in the mid-1980s, a qualitatively different form of terrorism appeared in the realm of aviation. This new phenomenon was also shaped and supported by shifts in the media sector, which accelerated the growth of its significance.

The hijacking by Lebanese Hezbollah terrorists of a TWA Boeing 727 airliner in July 1985-followed by a two-week-long hostage drama, the transfer of the seized plane between different airports in the Middle East, the murder of one of the passengers, and interviews with released hostages - was uninterruptedly broadcast by the major television networks in the United States. As a direct result, following the broadcasts of the episode, over 850,000 Americans declined going abroad for fear of an act of terror; another 200,000 decided to spend their holidays in the homeland. In a ripple effect, 50 percent of previously reserved American tours to Italy and 30 percent of tours to Greece were canceled, which essentially damaged the economies of these countries as well. ${ }^{5}$ This example is illustrative of changes in the dynamics of aviation terrorism, since it extended beyond an attack on a single branch of transportation and took on two new dimensions: economic and psychological warfare.

5 Hoffman, Terrorism, 182. 


\section{Current Dynamics of Aviation Terrorism}

In considering the examples discussed above, it is no mere chance that the largest terrorist attacks the world has ever seen - the September 11 attacks on New York and Washington - were committed by hijacking civil airliners. For the first time, the airplanes were steered by suicide pilots. Instead of being employed as leverage for negotiations or as a platform for putting forward demands, the airliners were used as weapons (in effect, manned cruise missiles) designed for defeating specific targets. The replacement of an unavailable class of weapons with other, available means is one of the fundamental principles of asymmetric warfare. In the meanwhile, to refuse talks or to elaborate demands against the backdrop of combat operations is an eloquent summation of the state of total war. This fact gave many experts cause to consider September 11, 2001 as the starting date of World War Four.

Present-day terrorism, when viewed as a particular type of war, increasingly assumes new forms, attributable to the military, economic, financial, and cultural-civilization asymmetries that arise when post-industrial and traditional societies are engaged in global conflict. It is the practical inability to endure direct confrontation with the regular military forces of developed countries that pushes non-state actors in the direction of non-conventional (i.e., terrorist) operational approaches.

The following examples may be cited. Two terrorist attacks in October 2002 - the bombing of two night clubs on Bali, Indonesia, and the attempt to shoot down an Israeli passenger aircraft in Kenya with a portable SAM - resulted in substantial decrease in the number of Western tourists, who traditionally spend their vacations in warm locales, in these parts of the world. Note that these synchronous operations, mounted at an interval of two weeks, not only caused damage to the tourist and entertainment sectors (which account for no less than 10 percent of spending in Western economies). The most affected sector at first proved to be air companies, which work as transport operators for tourist agencies. The same month's attack against a French supertanker off the coast of Yemen led to a temporary hike in prices in the oil markets worldwide, which also damaged the airlines, because they had to purchase jet fuel at higher rates. ${ }^{6}$ Thus, it is entirely safe to argue that terrorism is a highly effective instrument of economic warfare.

It should be noted that the air transportation sector is on the front lines of the war against terror. An indication of this fact is the large-scale systemic crisis that has affected the world's leading airlines following September 11, whose consequences have not yet been resolved. A number of well-known companies (Sabena, Swissair, etc.) failed to survive under force majeure circumstances, while other companies had to go to incredible lengths to survive. For instance, several major passenger carriers in the United States have filed for bankruptcy protection and, on the other side of the Atlantic, according to a special decision of the government, British Airways was declared exempt from paying basic taxes. Without this provision, the operation of the leading

6 J. Aras, interview with the Echo newspaper, 15 July 2003; available at: http://www2.echoaz.com/archive2/623/foreign. shtml. 
national airline of Great Britain would be unprofitable and, hence, senseless from an economic point of view. According to forecasts for 2004, this year British Airways is projected to lose another $\$ 900$ million, and 13,000 jobs (out of 45,000 ) will need to be cut.

An eloquent testimony to the scope of the terrorist threat to the functioning of the world's air traffic system proved to be the events that occurred between 24 December 2003 and 5 January 2004 (the Christmas and New Year holidays, when the size of the passenger flow sharply rises). A starting point of the crisis was "reliable" information from "unidentified" sources within intelligence services about a high alert level concerning potential hijacking of airliners by Al Qaeda operatives. As a result, numerous flights of various airlines were canceled, several airports closed, readiness in air forces was heightened (jet fighters made repeated sorties to accompany suspicious airplanes), an elevated level of preparedness for acts of terror - Code Orange - was imposed on the entire territory of the United States. ${ }^{7}$ In particular, flights from the U.S. to London, Mexico, and Paris were canceled or delayed. No less than six flights from Paris to Los Angeles were canceled as well. A backward wave of threats, according to unidentified information channels, was registered just a month later, in early February. As a consequence, British Airways flights to Washington and Air France flights to Los Angeles were postponed again. ${ }^{8}$

The immediate consequences of this crisis in civil aviation were the complication of registration and examination procedures for passengers and the institution of armed air marshals to escort commercial flights (this measure resulted in political tensions between the U.S. and some other states). ${ }^{9}$ The direct damage caused by the disruption of flight schedules and heightened security measures amounted to several tens of millions of USD; the secondary consequences (psychological depression and panic among potential passengers) are subject to no material calculation. In analyzing this incident, scores of counter-terrorism experts have assumed that this crisis in world air traffic was provoked not by real factors but rather by deliberate misinformation spread by terrorist structures through the exchange of false operational plans via e-mail in imitation of an actual threat.

Bearing further witness of the power of rumor to disrupt the world aviation system is a recurrent series of hoax threats that took place in September-October 2004. Following anonymous telephone calls regarding alleged explosives onboard, seven flights operated by Olympic Airways, Singapore Airways, El Al, and Lufthansa were either suspended or canceled. Air force jet fighters were alerted again, anti-terrorist units, police, rescue, and medical structures were mobilized, and the result was damage in the millions of USD. Thus, immediate actions are not necessary to disrupt the aviation system; rather, the mere threat of actions under the rubric of international terrorism imposes an effective combined formula of direct economic and psychological pressure on opponent.

7 Arab News, 3 January 2004. [a periodical daily newspaper, London]

8 Fox News; story available at: http://www.foxnews.com/story/0,2933,110006,00.html.

9 Arab News, 7 January 2004. 


\section{Classification of Threats}

Analyses of the modern dynamics and tendencies of international terrorism as a whole, and its numerous particular aspects, make it possible to single out the following categories of the existing threat framework as they relate to civil aviation:

- Aircraft hijacking for retention/exchange of hostages;

- Aircraft hijacking for movement/transfer;

- Aircraft hijacking for annihilation/destruction;

- Direct action against aircraft from outside;

- Direct action against civil aviation ground infrastructure;

- Peripheral categories of actions.

Category of actions

Hijacking for retention

Hijacking for movement

Hijacking for annihilation

Direct action against aircraft

Direct action against ground infrastructure

Peripheral categories
Aircraft + passengers

Aircraft + passengers

Object of actions

Passengers

Aircraft

Ground infrastructure (and, more rarely, aircraft or passengers)

Aircraft (and, more rarely, passengers, crew, ground infrastructure)
Aim of actions

Attaining political, propaganda, and psychological results; not connected to causing direct damage

Transferring of terrorists from one geographic point to another

Inflicting material, political, and psychological damage

Inflicting material, political, and psychological damage

Inflicting material, political, and psychological damage

Various

Hijacking for Retention. Passengers on board of an airplane are the primary objects of this category of actions. The aim is to achieve political, propaganda, and psychological effect (show of force and presence; pressuring state structures and public opinion; attraction of maximum attention; compliance with conditions and demands). A classical act of terror in the form of the forcible seizure of hostages on board of an aircraft and a demonstrative threat to their lives poses a practically unsolvable political and moral-psychological dilemma for the state, which is faced with the necessities of suppressing terrorism and saving the lives of hostages as diametrically opposite tasks. 
As effective means of pressure, this form of terror provides terrorists with an ample "window of opportunity," following which they are in a position to attain their goals..$^{10}$ There are tens of episodes where the hijacking of passenger airliners has been committed for the above-mentioned considerations. One example took place in November 1991, when a group headed by Shamil Basayev seized an Aeroflot Tupolev-154 airliner at the Mineralniye Vody airport and hijacked it to Turkey, establishing as a precondition for the release of the hostages the cancellation of the state of emergency that had been imposed by the Russian government in the Chechen-Ingush Autonomous Republic.

Hijacking for Movement. The airplane as a means of transportation is the primary target of this category of actions, with passengers acting as an additional factor enhancing safety guarantees for terrorists. The aim is to ensure the movement of terrorists from a territory that they are restricted or prohibited from exiting for some reason to another geographical point. In this category, seven acts of seizure of passenger airliners were committed in the USSR in 1990 alone in an effort to leave the country on the grounds of personal, political, or economic motivation. In some countries, this category of terror acts remains a marginal method of the migration of individuals, taken separately, or of small groups of persons with identical ideas. In particular, thirteen cases of hijacking of passenger airliners to Taiwan were registered in China from 1993-98. ${ }^{11}$ In March-April 2003, two Antonov-24 passenger planes were hijacked from Cuba to Florida. In some cases, acts of terror of this sort end with grave consequences that were unexpected by the organizers. In particular, the seizure and hijacking of an Ethiopian Airlines Boeing 767 in November 1996 by a group of separatists, owing to the inadequate training of the terrorists, ended with a crash-landing into the Indian Ocean off of the Comoros Islands, and the subsequent death of 125 passengers and crew members.

Hijacking for Annihilation/Destruction. Using an aircraft itself as a weapon for hitting a previously selected target is a primary object of this category of actions; passengers act as a factor, ensuring that an additional level of overall damage will ultimately result from the attack. The aim is to incur direct material damage to an adversary, in combination with collateral political and psychological damage. This category of actions is directly attributable to the parameters of asymmetrical warfare. The first operational precedent occurred in December 1994, when gunmen from the Algerian terrorist organization Armed Islamic Group (GIA) captured an Air France Airbus A-300 with 240 people on board in an attempt to explode it over Paris. It was a rescue operation at the intermediate landing point in Marcel mounted by a SWAT team that helped avoid potentially grave consequences. ${ }^{12}$

10 J. Aras, Terrorism: Yesterday, Today and Forever (Baku: Sada publishing house, 2003), $108-109$.

11 Aras, World War Four, 585.

12 E. Kozhushko, Modern Terrorism: An Analysis of Modern Trends (Moscow: Harvest, 2000), 330 . 
In October 2002, terrorists attempted to hijack a Saudi Airlines Airbus A-320 with the purpose of crashing it into a U.S. air base at Al-Udeid in Qatar. The culminating mega-terrorist attack within this category was the capture of four passenger airliners on 11 September 2001 and their subsequent use as cruise missiles against targets in Washington, D.C. and New York City. It should be noted that, despite heightened safety measures at airports and the introduction of appropriate technologies, the threat of this absolute use of aviation terrorism does not decrease, but rather increases. An eloquent testimony to this fact is the information that has been gathered about $\mathrm{Al}$ Qaeda operatives' testing of innovative techniques of seizing and hijacking airplanes, aiming to realize in practice a form of kamikaze (airplane as a delivery vehicle, suicide pilot as guidance unit). ${ }^{13}$ That is why it is not surprising today to see SAM firing units and radar arrays in capitals around the world, from Washington to Colombo, to thus protect key government facilities against "uninvited guests."

Direct Actions against Aircraft. Both airliners and passengers/crew on board are targets of this category of attack, whose aim is to destroy an aircraft in the air and annihilate people in order to incur material, political, and psychological damage. In practice, terrorists prefer to use improvised explosive devices (IED) and man-portable air defense systems (MANPADS), such as shoulder rocket-propelled grenade launchers (RPG), anti-tank guided missiles (ATGM), heavy and light machine-guns, anti-material sniper rifles, and assault rifles.

Improvised explosive devices with timers or barometric-work mechanisms of detonation proved to be effective means of destroying airliners in the 1980s. A requirement, however, was to place the explosives inside the target before departure, usually by putting them into unaccompanied luggage or transferring them to third persons without notifying them. As a result of the use of such explosives in particular, terrorists succeeded in destroying the airliners and passengers/crews of Pan American Flight 103 (Lockerbie, Scotland, December 1988, 271 casualties) and French UTA Flight 722 (Niger, July 1989, 170 casualties). There was also an attempt of this sort of terror act on board an Israeli Boeing-747 (London, 1986), where an explosive was deliberately placed by terrorist Nizar al-Hindaui in the luggage of his bride without his notifying her. With the improvement of technical and administrative measures of control of baggage and passengers, the threat of such acts of terror diminished in the early 1990s, although it has not been fully removed, especially since adversary parties have sought to find new, non-traditional forms of carrying and placing IEDs on airliners. In particular, an innovative step of this kind was the attempt at destroying an American Airlines aircraft bound from Paris for Miami in November 2001 by the terrorist John Reid, who placed a plastic explosive charge in heels of his own shoes.

Nowadays, the difficulty of placing the means of destruction directly on board of an airliner due to the intensification of technical security measures has been circumvented by a fundamentally new factor, in the form of such weapons as man-portable air de-

13 Rohan Gunaratna, “Al-Qaeda Adapts to Disruption," Jane's Intelligence Review (February 2004). 
fense systems. Used from outside an aircraft rather than from inside, MANPADS are presently one of the most serious threats to civil aviation. Contributing to this are the characteristics of this type of weapons:

- Utility: MANPADS constructively combine the functions of missile launch and guidance inside the same device.

- Small size: These weapons are easy to covertly move and store. The Soviet-made Strela-2 SAM (weight $13.6 \mathrm{~kg}$, length $1.5 \mathrm{~m}$ ) can easily be placed in a bag for golf clubs. A two-man team is required to transport most MANPADS and put them into combat readiness.

- Simplicity: The average time of high-level training for a MANPADS operator is five weeks (this includes practice launches; if a simulator is available, the term of training is three weeks).

- Reaction time: To bring the equipment into combat readiness for subsequent application against air targets, only several minutes are required.

- Technical specifications: MANPADS guidance systems (optical, infrared/thermal, radar) are designed to ensure high probability of hitting a target at heights up to approximately $3000 \mathrm{~m}$. Impact on a jet engine by a missile from an SA-18 Igla (weight of warhead is $1.18 \mathrm{~kg}$ ) during take-off or landing offers a 100 percent guarantee of the airliner's being disabled, and subsequent disaster. ${ }^{14}$

- Tactical specifications: Makes it possible to employ weapons using the protective features of a locality in the area of attack. Launch may be carried out from wooded areas, building roofs and windows, moving cars, etc.

- Low cost: Their relatively low price and wide distribution ensure that MANPADS are available on international arms black market to any interested player. Depending on market conditions, prices for these weapons range from $\$ 5,000$ for a Strela-2 to $\$ 20,000$ for a U.S.-made Stinger.

According to Pentagon estimates, there are 750,000 missiles and thousands of firing units currently in existence in the world, with a considerable portion being sold on the black market, deployed in armed conflict zones, and supervised by non-state actors, including insurgent and terrorist groups. In particular, the whereabouts and status of more than 1,000 Stinger SAMs, delivered through CIA channels to the Afghan mujahedeen in the 1980s to fight Soviet troops, remains unknown. According to indirect information, not less than 200 of the above-mentioned MANPADS are currently owned by various NSA groupings, ranging from Al Qaeda to the Kurdish Workers' Party. A portion of the 200 firing units and 2000 Strela-2M and Igla missiles that were left after the collapse of Marxist regime in Nicaragua are at the disposal of the narco-terrorist insurgent organization Revolutionary Armed Forces of Columbia (FARC). It should also be noted that no more than 1,000 out of 5,000 missiles for the said weapon that were deployed in Bosnia and Herzegovina during the armed conflict of 1992-95, have

14 A. Karpenko, Russian missiles: 1943-1993 (St. Petersburg: 1993), 85. 
been used, withdrawn, bought out, or destroyed; the status of others remains uncertain. In general, no less than twenty-seven terrorist groups presently possess either U.S.made Stingers, Soviet/Russian-made Strelas and Iglas of various modifications, British-made Blowpipes, French Mistrals, Swedish RBS-70s, Chinese HN-5s, or Pakistani Anzas, etc. ${ }^{15}$

A steady tendency toward the use or threatened use of MANPADS against civil aviation finds its parallel in an operational chronology of related incidents:

- On 28 October 2002, two missiles (supposedly Strela-2) were fired from a car at an Israeli El Al Boeing-757-300 on take-off from the airport in Mombasa, Kenya; due to missile malfunction and premature explosion, the aircraft was not practically damaged and kept on flying.

- In August 2003, three men from the Middle East were detained by FBI officers when trying to bring Igla-M SAM (NATO codename SA-18) missiles into the United States; a presumable aim of the delivery was to mount a terrorist attack against a civil aircraft.

- On 24 October 2003, an El Al Boeing-767, bound from Tel-Aviv to Los Angeles with 193 passengers on board, was diverted to a secondary airport due to urgent intelligence information about a prepared attack against the airliner using a portable SAM to be launched from a previously selected position in the area of the intermediate landing airport in Toronto. ${ }^{16}$

A clear illustration of the seriousness of this issue is a statement of the commander of the U.S. Transportation Command (USTRANSCOM), Lieutenant General John Handy: "In the course of global war against terrorism, the MANPAD threat is the greatest threat we have ever been faced with."17

It is necessary to add that terrorists are constantly seeking new, technically innovative and deadly methods to destroy aircraft from the ground. A striking confirmation of this effort was an attempt by an unknown (presumably domestic) terrorist to use a laser beam to affect the sight of an airliner's pilot during a landing in Salt Lake City in September 2004.

Direct Actions Against Ground Infrastructure. The target of this category of terrorist attacks is the supporting ground infrastructure of civil aviation. The aim is to incur material, political, and psychological damage and reaffirm the fact of war. Static technical infrastructure (passenger and cargo terminals, hangars, fuel tanks, air traffic radar, and other facilities), as well as aircraft on the ground remain vulnerable targets for assault with the purpose of takeover or destruction. This element of the terrorist threat framework is widespread. Confirmation can be found in two selective operational episodes in the context of the current civil wars in Sri Lanka and Colombia.

15 J. Aras, Terrorism, 119; Thomas B. Hanter, “The Proliferation of MANPADS," Jane's Intelligence Review (September 2001).

16 Izvestia, 27 October 2003.

17 USNI Military Databases; available at www.periscope.com. Quote from 20 November 2003. 
On 24 July 2001, a group of suicide combatants from the insurgent/terrorist organization Liberation Tigers of Tamil-Eelam (LTTE) conducted a surprise attack under cover of darkness on the international airport and an adjacent military airfield in the Sri Lankan capital Colombo. As a result of a fierce seven-hour battle, three Airbus passenger aircraft (2 A-330 and 1 A-340) belonging to Sri Lanka Airlines, as well as six aircraft and two helicopters of the Sri Lankan air force, were destroyed, and another three Airbus airliners were damaged. In addition, a building of the passenger terminal was destroyed, and an electricity power station and two aviation fuel storage tanks were burnt. The cost of the destroyed aviation equipment alone amounted to $\$ 400$ million. ${ }^{18}$ Note that the entire operation was carried out by just one raiding party, made up of twelve to fifteen gunmen, armed with automatic weapons, grenade launchers, and explosive charges.

In February 2004, Colombian security forces detected and defused four gas balloons laden with explosives and a remote control device, which were covertly deployed by a subversive group of the insurgent/terrorist organization Revolutionary Armed Forces of Columbia (FARC) from a road alongside a runway at the airport in Valdupar. Terrorists planned to launch their devices pending the arrival of Alvaro Uribe, the President of Colombia.

Incurring damage to civil aviation on the ground is not solely a method at the disposal of large armed groups, and may be applied not only to the infrastructure, but to passengers and personnel as well. In particular, groups of terrorists - numbering only three gunmen each-from the Japanese Red Army (JRA) and the Armenian Secret Army for Liberation of Armenia (ASALA) conducted armed attacks on passengers at airports in Tel-Aviv and Paris in 1968 and 1983, killing twenty-six and five people, respectively. In July 2002, a U.S. citizen named Hisham Hidayat, acting absolutely independently, on the grounds of national enmity and religious fanaticism, committed an armed assault on passengers being registered at an $\mathrm{El} \mathrm{Al}$ counter at Los Angeles International Airport, killing two passengers and wounding three. This last case was possible due to the negligence of the airport security service, in spite of the fact that this service has been acting under the heightened state of alert imposed in U.S. airports after $9 / 11$.

Peripheral Categories. This category does not pertain to acts that are specifically terroristic in nature, but to acts that, by their parameters (criminal character), or their immediate and long-term consequences, are compatible with terrorism. Targets of this category of actions are largely aircraft, and more rarely passengers, crew, and the supporting ground infrastructure of civil aviation. Its aims are different from posing a direct or indirect threat on board of an airliner, and are differently motivated. These include:

- Use of civil aviation by figures of international terrorism for transportation (that is, for indirect support of terrorist activity);

18 Jane's Information Group; see http://www.janes.com/security/international_security/news/ misc/janes010724. 
- Use of civil aviation by figures of transnational organized crime as means of carrying out illegal activities;

- Forcible actions on board airliners on the basis of deviant social or psychic behavior of individual passengers or groups of passengers.

Participants in international terrorism at all levels often use civil aviation for its intended purpose: transportation. Civil aviation is the fastest and most convenient means of concealed transit on the basis of legal or forged travel documents, especially when one wants to cover considerable distances in a short time. Note that airliners and passengers are subject to no danger in this case; the danger is realized on the territories of the destination (or other) countries, which are targets of terrorist operations. There is also a probability that civil aviation is used as a means to transport operational documents, propaganda materials, and - to a lesser degree-weapons, ammunition, explosives, and radioactive and poisonous substances (although the latter are more likely transported via cargo aviation). Another aspect, although less widespread and yet likely, is the use of civil aircraft as a means of bringing terrorists and hostages to a certain geographical point following the commission of an act of terror beyond the sphere of civil aviation (example: the episode of taking secondary school pupils as hostages in the North-Ossetian Autonomous Republic of Russia by a gang led by Paul Yakshiyants in 1988).

The current active convergence of international terrorism and transnational organized crime is a relatively new factor in the sphere of indirect threats to aviation security. It should be noted that civil aviation is objectively sphere of interest to criminal entities, who are engaged in such activities as illegal migration, drug trafficking, money laundering, and smuggling weapons, ammunition, works of art, etc. A certain portion of the operations and movements of criminal organizations are carried out using regular passenger flights within the framework of normal passenger and cargo flows under the cover of both legal and forged documents. The threat posed by organized crime may be regarded as indirect, in consideration of the fact that a basic task of organized criminal networks is the movement of subjects and items of criminal activity (people, drugs, cash, etc.) between remote geographical points as covertly and rapidly as possible. Owing to the fact that transnational criminal organizations have joined forces with international terrorists and are part of their financial resource base, the involvement of these criminal groups cannot be ignored in the light of the struggle against terrorism.

Deviant social behavior on the part of individuals or groups on board airliners may under certain circumstances create conditions that can either cause an aviation disaster or threaten the life of passengers. These are primarily acts of hooliganism caused or aggravated by alcoholic or narcotic intoxication. Specific categories of passengersfans of soccer teams or and music groups, youth tourism groups, crews of fishing boats, etc.- represent a source of heightened danger. The combination of the sedative effect of alcohol and the feeling of impunity often displayed by members of such groups is frequently a trigger for increased aggression. This is confirmed, for example, by a virtual riot that took place between tourists on board of an Aeroflot flight from 
Hurghada (Egypt) to Moscow in 1996. The numbers bear out the point: 300 cases of hooliganism were reported on British Airways flights in 2003, and 126 cases on Aeroflot flights. ${ }^{19}$ Whereas 1994 saw 1,132 reported cases of the violation of airline behavior rules worldwide, the figure had risen to 5,416 by 1997 (as recorded by the International Aviation Transport Association).

Actions on board of an aircraft carried out by passengers with mental illness pose a particular danger to the lives of passengers. In one instance, a mentally-ill Italian national, Stefano Sabarini, having proclaimed himself the founder of a new religion, was captured in March 1999 on an Air France Airbus A-320 bound for Paris from Marcel, and again in November 2002 on an Alitalia Airbus A-320 bound for Paris from Bologna. ${ }^{20}$ This is a striking illustration of the ineffective work of European security services in the area of civil aviation, as they failed to prevent a person who was widely known to be dangerous from boarding the flights. In November 2002, a mentally-ill Israeli citizen, Taufik Al-Furka, tried to hijack an El Al flight bound from Tel Aviv for Istanbul, but his attempt was prevented by security agents on board. In March 2003, Ozgur Gekaslan, from Turkey, seized and hijacked a Turkish Airlines aircraft to Athens. The investigation and medical examination identified in both cases evidence of mental disorders, aggravated by an array of social and personal problems. In considering the particularly dangerous character of the above-mentioned actions, which were fraught with potentially grave consequences both for civil aviation and a wider scale, there is good reason to classify these peripheral threats as actions that fall under an enlarged definition of terrorism.

\section{Difficulties in Air Transport Security in Azerbaijan}

Arising from the general tendencies outlined above are threat parameters in the realm of air transportation that are of particular importance for Azerbaijan, due to the country's unique position in the global system of terrorist threats. Of critical importance is the fact that Azerbaijan is situated at the junction of several unstable geopolitical areas (Caucasus, Caspian basin, Black Sea basin, Central Asia, Middle East, the Persian Gulf). In addition, it possesses considerable energy resources (oil and natural gas) and is a participant in several international geo-economic projects. ${ }^{21}$ Such a concurrence of factors is, beyond any doubt, reflective of the country's growing importance in terms of incipient global trends of the twenty-first century in the spheres of economics and security. At the same time, the nation's position has its seamy side, particularly a growing threat that Azerbaijan is increasingly near to the focus of operational activity of different terrorist entities, particularly participants in the global conflict whose structural format has been altered in the wake of $9 / 11$.

19 Izvestia, 27 April 2004.

20 Aras, World War Four, 556.

21 J. Arasly, presentation at a meeting of the PfP Consortium's Combating Terrorism Working Group, West Point, September 2003. 
This is true in the area of civil aviation security as well. Azerbaijan's geographical location primarily accounts for its significance in the flow of international traffic, including air transportation. It was dynamics that resulted from the continuing conflicts in Afghanistan and Iraq, as well as the development of oil resources in the Caspian Sea, that provided the initial impetus to reorient additional passenger and cargo air routes through Azerbaijan. On the other hand, the above-mentioned factors also contribute to an unstable military-political background in the region as a whole. Further complicating the issue is the as yet unsettled conflict between Armenia and Azerbaijan, and the aggravation both of regional (Chechnya, Abkhazia, the Kurdish question) and global problems (international terrorism, transnational organized crime, migration). The point is that Azerbaijan runs the risk of being pulled into the political and operational vortex of several transnational and local terrorist groups that are operating on the regional stage. Those groups that offer the greatest danger are:

- A conglomeration of Armenian terrorist groups, previously operating under the banner of the Armenian Secret Army for Liberation of Armenia;

- Regional structures of the transnational Al Qaeda network;

- Structures of the separatist Kurdish Worker's Party (PKK) and the Congress of Democracy and Freedom of Kurdistan (KADEK) and its local branches;

- Internal factions of the Iranian opposition group Mojahedin-e-Khalk, which are currently operating independently from the central group;

- Structures of the Iraqi religious-political group Ansar al Islam;

- Various structural elements of the Chechen separatist movement.

This essay does not aim to examine the operational parameters, ideologies, or political motivations of these organizations. Still, it is appropriate to note that all of them have previously been known to employ terrorism against civil aviation. Also, one cannot ignore the global fact that Azerbaijan is located in a region that has become an operational-transit zone for transnational organized crime.

\section{Conclusion}

While making no claims to offer a comprehensive and thoroughly expert analysis, the author dares to consider matters relating to the struggle against terrorism from the perspective of civil aviation, and to make some recommendations for actions that should be taken. Below are the functional categories into which these actions may be sorted:

1.Improvement of the air transport security system. This would include toughening procedures relating to the purchase of airline tickets and to the registration and examination of passengers and cargo to rule out bringing individuals and articles on board that could pose even the slightest threat to passengers' safety. It would also involve increasing technical standards of control and security, forming exclusive security zones around airports, and improving the all-around training of security service employees. 
2.Improvement and introduction of technical protection measures for aircraft. Provides for the use of electronic means of protection against MANPADS launches.

3.Introduction of preventive measures aimed at averting acts of terror. This would include the creation of databases on potentially dangerous passengers; more stringent pre-screening for members of radical political organizations, religious sects, criminal groups, those who are already or likely to become intoxicated, those skilled in hand-to-hand combat, etc.; and more thorough vetting of flight crews and technical personnel employed by the airlines.

4. Coordination of efforts and expansion of interaction between civil aviation bodies and state security services. This would involve forging closer ties between airlines and civil aviation authorities and the armed forces, special and secret services, law enforcement, immigration, and customs agencies within the framework of combating international terrorism and organized crime.

5.Improvement of the international legal mechanism of counteracting aviation terrorism. Current conventions are not enough to properly coordinate the actions of states to combat terrorist threats on civil aviation.

6. Expansion and deepening of the interaction between relevant professional structures at the regional and international levels. This includes rendering organizational, financial, and technical assistance to separate states that are located in areas of heightened risk in terms of air transport and traffic operations.

I am aware that putting these suggestions into effect is difficult not only from the organizational and financial standpoint, but also on political, moral, and ethical grounds as well. Taking fingerprints and scanning retinas of airline passengers, and using armed air marshals on flights are all adverse to the principles of democracy and individual freedom. This can simply be added to the list of the numerous negative consequences of the phenomenon of international terrorism. To sum up, I must ultimately arrive at pessimistic conclusion: terrorism will exist as long as humanity does. Even worse, its trajectory is currently on the ascent. Hence, the problem of air transport security is more critical than ever before. 
THE QUARTERLY JOURNAL

\section{Bibliography}

Aras, J.. Terrorism: Yesterday, Today and Forever. Baku: Sada publishing house, 2003.

Aras, J.. World War Four. The Handbook on Non-government Paramilitary Systems. Baku: Sada publishing house, 2002.

Gubarev, O.. Secrets of Air Terrorism. Moscow: Veche, 2002.

Gunaratna, Rohan. "Al-Qaeda Adapts to Disruption." Jane’s Intelligence Review (2004).

Hoffman, Bruce. Terrorism. The Insight. Moscow, 2003.

Karpenko, A.. Russian missiles: 1943-1993. St. Petersburg, 1993.

Kozhushko, E.. Modern Terrorism: An Analysis of Modern Trends . Moscow: Harvest, 2000 . 